\title{
Spatial distribution of nymphs and adults of Euschistus heros (Fabricius, 1794) (Heteroptera: Pentatomidae) in transgenic soybean cultivars of different maturing cycles
}

\section{Distribuição espacial de ninfas e adultos de Euschistus heros (Fabricius, 1794) (Heteroptera: Pentatomidae) em cultivares transgênicas de soja de diferentes ciclos de desenvolvimento}

\author{
Leandro Aparecido de Souza ${ }^{1 *}$; José Carlos Barbosa ${ }^{2}$; Oniel Jeremías Aguirre-Gil³; \\ Daniela de Lima Viana ${ }^{3}$; Leticia Serpa dos Santos ${ }^{3}$; Antonio Carlos Busoli ${ }^{2}$
}

\begin{abstract}
The neotropical stink bug Euschistus heros is the predominant and most important insect pest affecting soybean cultivation. Knowledge of the spatial pattern of the pest in an area is critical to understanding its behavior. The objective of this work was to study the spatial distribution of $E$. heros in transgenic soybean cultivars of different maturing cycles. The experiments were conducted in the seasons 2013/14 and 2014/15 in FCAV/UNESP, Jaboticabal, SP. Three fields were selected, and each was marked an area of $8.000 \mathrm{~m}^{2}(0.8 \mathrm{ha})$, with each area divided into 80 portions of $100 \mathrm{~m}^{2}(10 \mathrm{~m} \times 10 \mathrm{~m})$. The transgenic soybean cultivars of different maturing cycles were: SYN 1365 RR (early), M 7908 RR (average), and BRS Valiosa RR (late). Samples were taken weekly using a beat sheet, registering the number of nymphs and adults of E. heros. To study the dispersion of E. heros, the following indices were used: variance/ mean ratio, Morisita index, Green coefficient, and the exponent $\mathrm{k}$ of the negative binomial distribution. For studies of special distribution models of E. heros, adjustments of Poisson distribution and negative binomial distribution were tested. The spatial distribution of nymphs and adults was aggregated for all the cultivars studied, indicating that cultivars did not alter the distribution behavior of $E$. heros.
\end{abstract}

Key words: Glycine $\max ($ L.). Behavioral ecology. Dispersion. Negative binomial distribution. Neotropical brown stink bug.

\section{Resumo}

O percevejo-marrom-da-soja Euschistus heros, destaca-se como o inseto-praga predominante e mais importante na cultura. $\mathrm{O}$ conhecimento do padrão espacial da praga na área é fundamental para o entendimento do seu comportamento. $\mathrm{O}$ objetivo do presente trabalho foi estudar a distribuição espacial de $E$. heros em cultivares de soja transgênica de diferentes ciclos de desenvolvimento. Os experimentos foram conduzidos nos anos agrícolas 2013/14 e 2014/15 na FCAV/UNESP, Jaboticabal, SP. Foram selecionados três campos, e em cada um foi demarcada uma área de $8.000 \mathrm{~m}^{2}(0,8 \mathrm{ha})$, sendo cada área

1 Prof. Dr., Faculdade Quirinópolis, FAQUI, Quirinópolis, GO, Brasil. E-mail: leandroagronomia@hotmail.com

2 Profs. Drs., Universidade Estadual Paulista "Júlio de Mesquita Filho", Faculdade de Ciências Agrárias e Veterinárias, FCAV/ UNESP, Jaboticabal, SP, Brasil. E-mail: jcbarbosa@fcav.unesp.br; acbusoli@fcav.unesp.br

3 Discentes de Doutorado, Universidade Estadual Paulista “Júlio de Mesquita Filho", Faculdade de Ciências Agrárias e Veterinárias, FCAV/UNESP, Jaboticabal, SP, Brasil. E-mail: oaguirretm@outlook.com; danielaviana28@gmail.com; leserpa15@hotmail. com

* Author for correspondence 
subdividida em 80 parcelas de $100 \mathrm{~m}^{2}(10 \mathrm{~m} \times 10 \mathrm{~m})$. As cultivares de soja transgênica de diferentes ciclos de desenvolvimento utilizadas foram: SYN 1365 RR (precoce), M 7908 RR (média) e BRS Valiosa RR (tardia). As amostragens foram realizadas semanalmente usando pano de batida, registrando-se o número de ninfas e adultos. Para o estudo da dispersão de $E$. heros foram utilizados os seguintes índices: razão variância/média, índice de Morisita, coeficiente de Green e o expoente $k$ da distribuição binomial negativa. Para os estudos dos modelos de distribuição espacial de $E$. heros foram testados os ajustes das distribuições de Poisson e distribuição binomial negativa. A distribuição espacial de ninfas e adultos foi agregada para todas as cultivares em estudo, ou seja, as cultivares não alteram o comportamento de distribuição de E. heros.

Palavras-chave: Glycine $\max (L$.$) . Ecologia comportamental. Dispersão. Distribuição binomial$ negativa. Percevejo-marrom-da-soja.

\section{Introduction}

The soybean, Glycine max (L.), crop is susceptible to numerous insect pests that directly and indirectly affect the productivity of this legume. The neotropical stink bug, Euschistus heros (Fabricius, 1794) (Heteroptera: Pentatomidae), stands out as the predominant and most important pest species in Brazil in relation to this crop (SOSA-GÓMEZ; SILVA, 2010; BUENO et al., 2015).

Pest control of E. heros is generally carried out with chemical insecticides. However, E. heros, which falls within the Pentatomidae family, has been showing resistance to several groups of organophosphate insecticides (metamidofos, acephate, chlorpyrifos, and monocrotophos) and cyclodienes (endosulfan), which makes it difficult to control the pest and increases crop production costs (SOSA-GÓMEZ; OMOTO, 2012).

Moreover, soybean production has undergone major changes, including the increasing use of genetically modified crops, which can directly or indirectly affect the behavior of insect pest populations in the agroecosystem (RODRIGUES et al., 2010). In addition, the use of early-maturity cultivars and the area under cultivation are increasing (BUENO et al., 2012).

To understand the behavior of insect pests, it is essential to study their spatial distribution. The patterns of spatial distribution of pests in cultivated areas can be regular (uniform), random, and aggregated (contagious). These distributions cloud be binomial positive, Poisson, and negative binomial, respectively (PERECIN; BARBOSA, 1992).

According to Souza et al. (2013), the spatial distribution of nymphs from the $1^{\text {st }}$ to the $3^{\text {rd }}$ instars of $E$. heros was aggregated and the adult population had a dispersion pattern that varied from moderately aggregated to random.

Fonseca et al. (2014), in a study performed at two locations in the state of Mato Grosso do Sul, Brazil, confirmed that E. heros nymphs showed an aggregated spatial pattern, which best fits the negative binomial distribution, in both Bt soybean and non Bt soybean cultivars. Regarding adults, the dispersion pattern varied from aggregated to uniform, according to the stage of development of the crop.

It is also worth noting that, based on information of spatial distribution, it is possible to develop sequential sampling plans, which are characterized by using samples of variable sizes instead of using a fixed number of samples for a given area (BARBOSA, 1992).

Sequential sampling has an advantage over conventional sampling because it allows for a reduction in the total number of sample units per area, and consequently the time and costs involved in the sampling operation are reduced (WALD, 1945, 1947).

It is further noteworthy that information of the spatial distribution of insect pests at different 
development stages of genetically modified soybean cultivars is scarce. In this context, the objective of the present study was to determine the spatial distribution of $E$. heros in genetically modified soybean cultivars during various stages of development.

\section{Materials and Methods}

The experiments were conducted at the Teaching, Research, and Extension Farm (FEPE) at the Faculty of Agrarian and Veterinary Sciences, UNESP - Jaboticabal Campus, São Paulo, whose coordinates are: latitude $21^{\circ} 14^{\prime} 05^{\prime \prime} \mathrm{S}$, longitude $48^{\circ} 17^{\prime} 09^{\prime \prime} \mathrm{W}$, and altitude $615.01 \mathrm{~m}$. The experiments were conducted over two cropping seasons: the 2013/14 and 2014/15 cropping seasons. According to the Köppen classification, the climate of the region is classified as "Aw" with average temperature of $23.2^{\circ} \mathrm{C}$ and total annual precipitation of approximately $1405.2 \mathrm{~mm}$ (CEPAGRI, 2017).

The cultivars of various development stages were: SYN 1365 RR (early), M 7908 RR (normal), and BRS Valiosa RR (late). The cultivars were planted in December 2013 and November 2014, with spacing of $0.45 \mathrm{~m}$ between rows. Crop was carried out in a no-tillage system with straw retained on the soil surface, and was performed according to the technical recommendations for the region, following the fertilization and liming recommendations for the state of São Paulo (MIRANDA et al., 1998). To avoid any interference with the results, no insecticide sprays were performed during the experiment.

Three fields were selected in an agricultural production area. In each field, with an area of 8,000 $\mathrm{m}^{2}$ (0.8 ha), was demarcated, and each area was subdivided into 80 plots of $100 \mathrm{~m}^{2}(10 \mathrm{~m} \mathrm{x} 10 \mathrm{~m})$. Within each sampling unit (with an area of 100 $\mathrm{m}^{2}$ ), five randomly selected sample points were examined.

To estimate the density of stink bugs, the beat sheet technique was used (BOYER; DUMAS,
1963). A beat sheet measuring $1 \mathrm{~m}$ in length by 0.5 $\mathrm{m}$ in width was used to assess stink bug density in $2 \mathrm{~m}$ of a planted row within the crop. Thirty plants were sampled with each beat sheet, since each meter of the row had approximately 15 plants.

The number of nymphs and adults present in each "beat sheet" were recorded for each sample unit. The samplings were performed weekly during the period of growth of the crop. It should be noted that the data assessment periods used were 50 to 127 days after emergence (DAE) during the 2013/14 season and 51 to 128 DAE during the 2014/15 season. Since the incidence of E. heros was higher at these times, it was possible to study its spatial distribution. This period corresponded to the stages of initial flowering (R1) to full maturity (R8) according to the scale proposed by Fehr and Caviness (1977).

For the spatial distribution analysis of E. heros data, we calculated the means and the variances of the average number of nymphs and adults per plot (five beat sheet samples) for each sampling season.

The dispersion indices used to verify the degree of aggregation of the E. heros brown stink bug, described below, were calculated with the aid of Microsoft Excel ${ }^{\circledR}$.

\section{Indices of dispersion}

\section{Variance-to-mean ratio}

This is the most common index, and is also called the index of dispersion. It is the relationship between the variance and the mean $\left(I=s^{2} / m\right)$, used for measuring the deviation from an arrangement of random conditions, in which values equal to 1 indicate a random spatial distribution, values less than 1 indicate a uniform distribution, and values greater than 1 indicate aggregated distribution (RABINOVICH, 1980). The distance of randomness can be tested by the chi-square test with $n-1$ degrees of freedom, $\chi^{2}=(\mathrm{n}-1) \mathrm{s}^{2} / m$ (ELLIOTT, 1979). 


\section{Morisita index}

This index was developed by Morisita in 1962. A value equal to 1 indicates random distribution, values greater than 1 indicate contagious distribution, and values less than 1 indicate regular or uniform distribution (MORISITA, 1962).

\section{Green's coefficient}

This index ranges from zero (for random distributions) to 1 (for maximum positive contagiousness). Negative values indicate a uniform distribution (GREEN, 1966).

\section{Exponent $k$ of the negative binomial distribution}

This parameter is an indicator of arthropod aggregation, and it occurs when the data fit a negative binomial distribution (SOUTHWOOD, 1978; ELLIOTT, 1979).

With this index, negative values indicate a uniform distribution, low and positive values $(k<$ $2)$ indicate a highly aggregated disposition, values ranging from 2 to 8 indicate a moderate aggregation, and values above 8 indicate a random distribution (ELLIOTT, 1979; COSTA et al., 2010).

Probabilistic models for the study of spatial distribution

For each sample, we tested the fit to the Poisson distribution and to the negative binomial distribution. It should be emphasized that a model has a good fit to the original data when the observed and expected frequencies are close. This relationship was tested by using the chi-square test $\left(X^{2}\right)$.

\section{Poisson distribution}

This is the distribution that best represents the random spatial distribution of insects and is characterized by a variance equal to the mean $\left(\sigma^{2}=\right.$ н) (SOUTHWOOD, 1978).

Negative binomial distribution

This type of distribution has a variance greater than the mean $\left(\sigma^{2}>\mu\right)$, and has two parameters: the mean $(m)$ and the exponent $k(k>0)$ (TAYLOR, 1984).

\section{Results}

Indices of dispersion for E. heros nymphs

With respect to the 2013/14 season and the SYN 1365 RR cultivar (early maturing), the results obtained for the $I$ index of dispersion (the varianceto-mean ratio) showed $75 \%$ of the values higher than 1, indicating aggregated distribution (Table 1). For the Morisita Index (Id), $75.0 \%$ of assessment results showed values greater than 1 , indicating aggregated distribution (MORISITA, 1962). For the Green coefficient $(C x), 75.0 \%$ of the results also showed values higher than 1 , also indicating aggregated distribution (GREEN, 1966). 


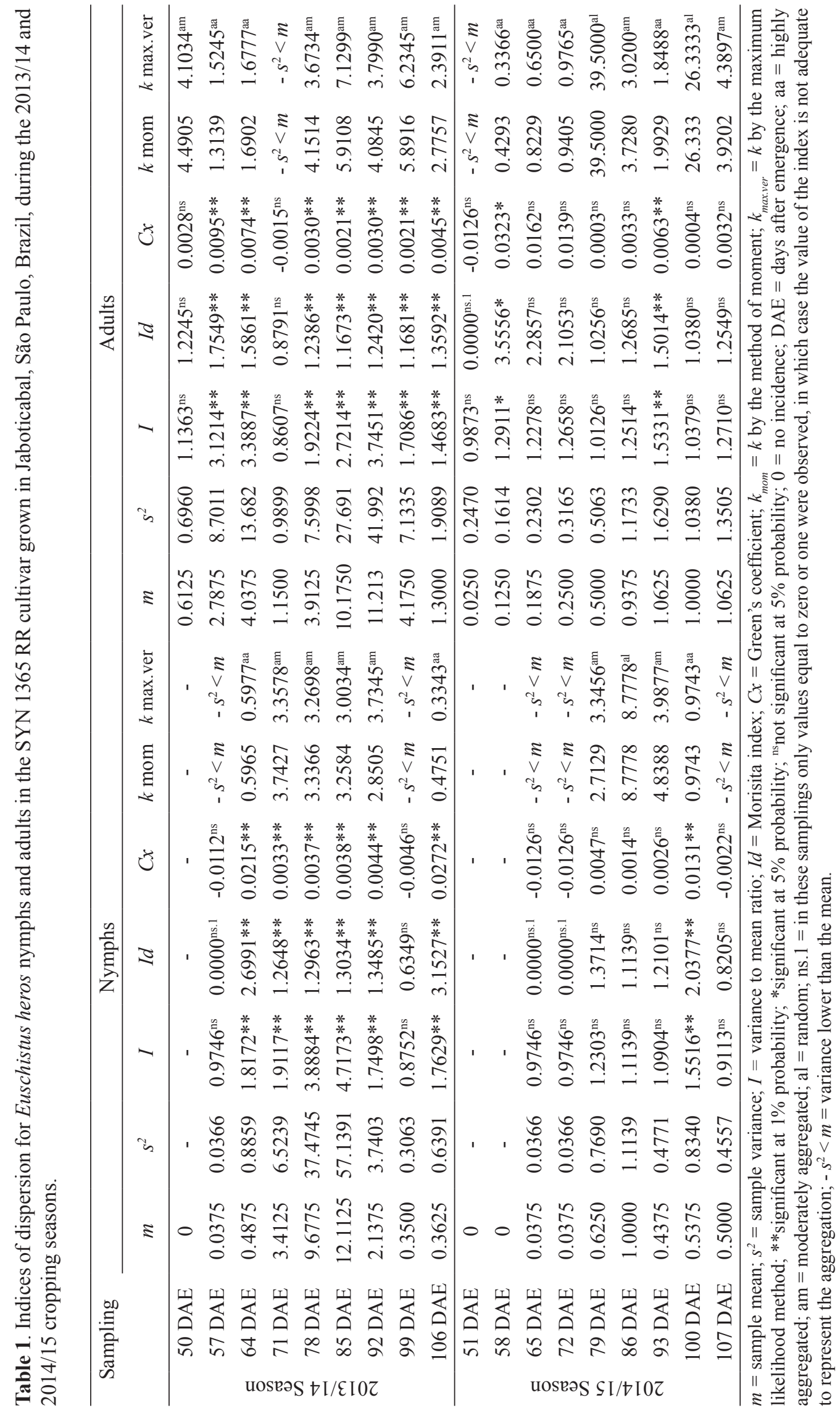


For the exponent $k$ of the negative binomial distribution, low and positive values $(k<2)$ were observed in $25.0 \%$ of the assessments, indicating highly aggregated disposition. Values ranging from 2 to 8 were found in $50.0 \%$ of the assessments, indicating moderate aggregation (ELLIOTT, 1979; COSTA et al., 2010).

Regarding the 2014/15 season, for the index of dispersion of the variance-to-mean ratio $(I)$ and the Morisita Index $(I d), 85.7 \%$ of values did not differ from 1 , which indicates a random distribution (Table 1). It is noteworthy that the lower incidence contributed to this tendency toward randomness. For Green's coefficient $(C x), 85.7 \%$ of the results showed values that did not significantly differ from zero, indicating random distribution (Table 1). For the exponent $k$ of the negative binomial distribution, $14.2 \%$ of results had values lower than 2 , and $42.8 \%$ of the results had values between 2 and 8 , indicating highly aggregated and moderately aggregated distribution, respectively.

For the M 7908 RR cultivar (normal maturity cycle), with respect to the 2013/14 cropping season, the results obtained indicated values of $I$ and $I d$ that were higher than 1 in $75.0 \%$ of the assessments, indicating aggregated distribution (Table 2). For Green's coefficient (Cx), 75.0\% of the assessments showed positive values greater than zero, indicating an aggregated pattern of distribution (Table 2).

For the dispersion index for the exponent $k$ of the negative binomial distribution, there were low and positive values $(k<2)$ in $75 \%$ of the assessments, indicating a highly aggregated pattern. For this, $12.5 \%$ of the values varied between 2 and 8 , indicating moderate aggregation (Table 2).

For the 2014/15 cropping season, $62.5 \%$ of the results had values of $I$ and $I d$ that did not significantly differ from 1 , indicating randomness
(Table 2). For the Green's coefficient $(C x), 62.5 \%$ of the assessments showed values that did not significantly differ from zero, indicating random distribution (Table 2).

For the exponent $k$ of the negative binomial distribution, $25.0 \%$ of the values were lower than $2,37.5 \%$ of the values varied between 2 and 8 , and $25.0 \%$ of the values were greater than 8 . These results indicate a highly aggregated pattern, moderate aggregation, and random distribution, respectively (Table 1).

For the BRS Valiosa RR (late maturing) cultivar during the 2013/14 cropping season, the values of $I$ and $I d$ greater than 1 were observed in $55.5 \%$ of the assessments, indicating an aggregated distribution (Table 3). In addition, 55\% of Green's coefficient $(C x)$ values were positive or greater than zero, also indicating an aggregated distribution pattern (Table 3).

For the exponent $k$ of the negative binomial distribution, low and positive values $(k<2)$ were observed in $55.5 \%$ of the assessments, indicating a highly aggregated disposition, while $33.3 \%$ of the assessments showed values ranging from 2 to 8 , indicating moderate aggregation.

For the 2014/15 harvest, $57.1 \%$ of the values obtained in the $I$ and $I d$ indices of dispersion did not significantly differ from 1 , indicating a pattern of random distribution (Table 3). For the Green's coefficient $(C x), 57.1 \%$ of the values were equal to zero, indicating randomness (Table 3 ).

For the exponent $k$ of the negative binomial distribution, $14.2 \%$ of the values were lower than $2,28.5 \%$ of the values varied between 2 and 8 , and $42.8 \%$ of the values were greater than 8 . These results indicate a highly aggregated pattern, a moderate aggregation, and a random distribution, respectively (Table 3). 


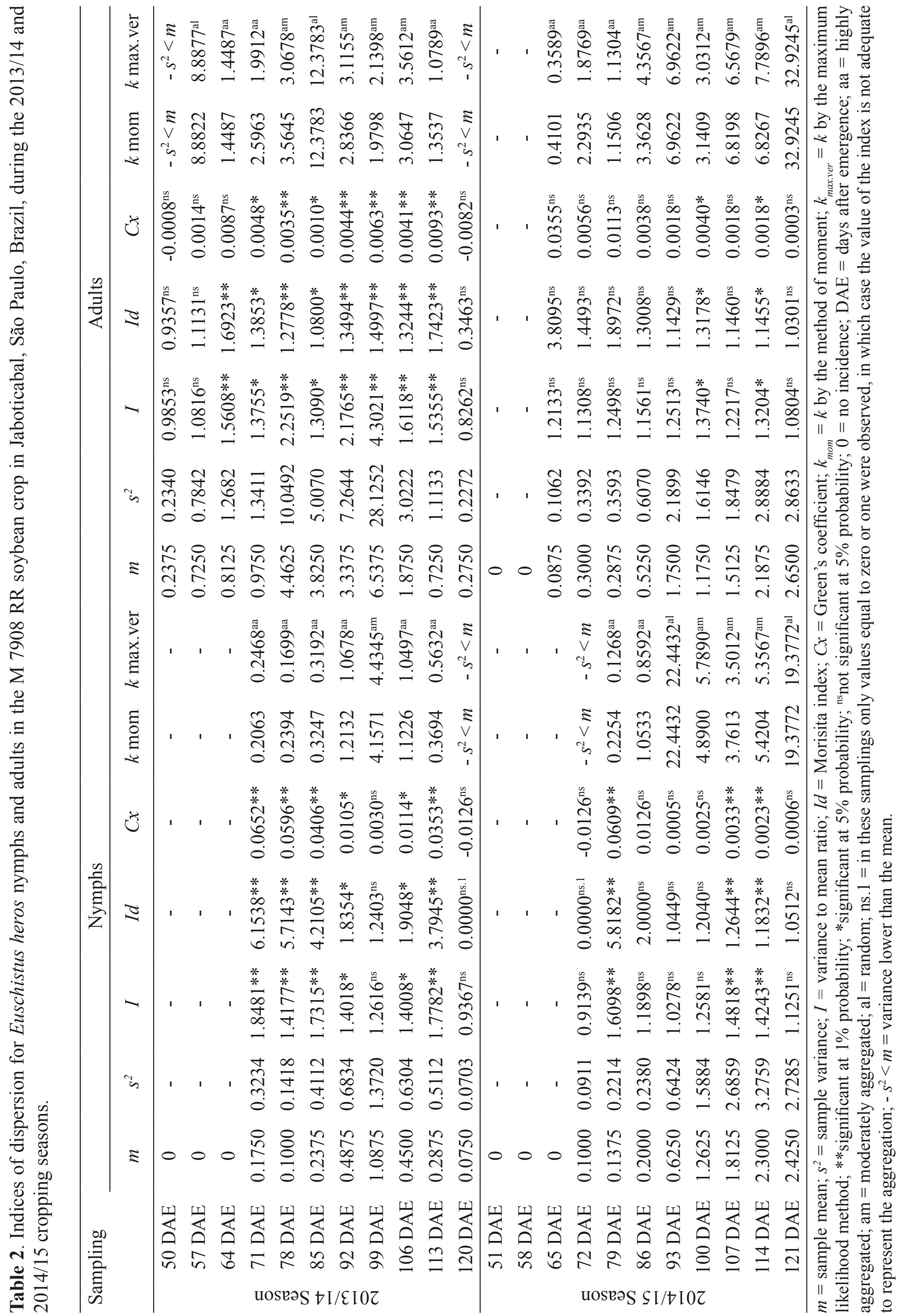




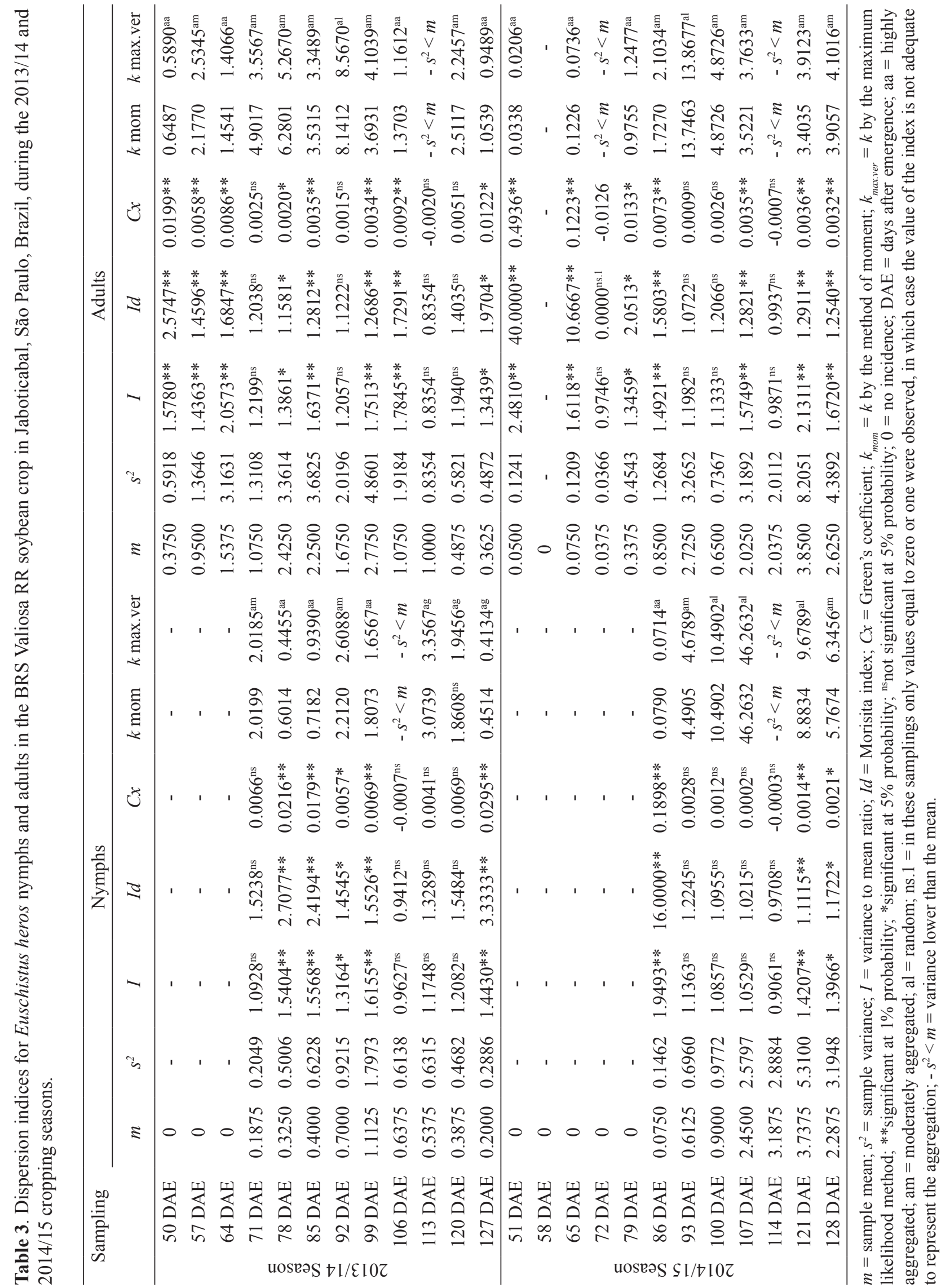


Indices of dispersion for E. heros adults

For the SYN 1365 RR cultivar during the 2013/14 cropping season, $77.7 \%$ of the values for the $I$ and $I d$ indices of dispersion were greater than 1 , indicating aggregated distribution (Table 1). In $77.7 \%$ of the assessments, the values for the Green's coefficient $(C x)$ were positive and greater than zero, indicating aggregated distribution (Table 1). For the exponent $k$ of the negative binomial distribution, low and positive values $(k<2)$ were observed in $22.2 \%$ of the assessments, indicating high aggregation, while $66.6 \%$ of the assessments showed values varying between 2 and 8, indicating moderate aggregation (Table 1).

For the indices $I$ and $I d$ in the 2014/15 cropping season, $77.7 \%$ of the values were equal to 1 , indicating a random pattern of distribution (Table 1). For the Green's coefficient $(C x), 77.7 \%$ of the samplings showed values equal to zero, indicating randomness (Table 1). For the exponent $k$ of the negative binomial distribution, $44.4 \%$ of the values were smaller than $2(k<2), 33.3 \%$ of the values were between 2 and 8 , and $22.2 \%$ of the values were greater than 8 . These results indicate highly aggregated distribution, moderate aggregation, and random distribution, respectively.

For the $I$ and $I d$ indices during the 2013/14 harvest, the dispersion values for the M 7908 RR cultivar were higher than 1 in $72.7 \%$ of the assessments, indicating aggregated distribution (Table 2). The $C x$ values were equal to zero in $72.7 \%$ of the samples, also indicating an aggregated distribution pattern (Table 2). With respect to the results for the exponent $k$ of the negative binomial distribution, there were low and positive values $(k<$ 2 ) in $27.2 \%$ of the assessments, indicating a highly aggregated distribution pattern, while $36.3 \%$ of the values were between 2 and 8 , indicating moderate aggregation, and $18.1 \%$ of values were greater than 8 , indicating a random pattern of distribution (Table 2).
For the $I$ and $I d$ indices of dispersion during the 2014/15 cropping season, values equal to 1 were observed in $77.7 \%$ of the assessments, indicating randomness (Table 2). For $C x, 77.7 \%$ of the assessments showed values equal to zero, indicating randomness and corroborating the results obtained by the variance ratio and the Morisita index (Table 2 ). With respect to the results of the exponent $k$ of the binomial negative distribution, $33.3 \%$ of the values were lower than $2,55.5 \%$ of the values were between 2 and 8 , and $11.1 \%$ of values were higher than 8 . These results indicate a highly aggregated pattern, a moderate aggregation, and a random distribution, respectively (Table 2 ).

For the BRS Valiosa RR cultivar during the 2013/14 cropping season, the results showed $I$ and $I d$ values higher than 1 in $66.6 \%$ of the assessments, indicating aggregated distribution (Table 3). According to the results obtained for the Green's coefficient $(C x)$, we observed positive values above zero in $66.6 \%$ of the assessments (Table 3 ), indicating an aggregated distribution pattern (GREEN, 1966). For the exponent $k$ of the negative binomial distribution, we found positive and low values $k<$ 2) in $33.3 \%$ of the assessments, indicating a highly aggregated disposition, while $50.0 \%$ of values were between 2 and 8, indicating moderate aggregation, and $8.33 \%$ of values were higher than 8 , indicating a random pattern of distribution (Table 3 ).

During the 2014/15 harvest, the results showed $I$ and $I d$ values higher than 1 in $63.6 \%$ of the assessments, indicating aggregated distribution (Table 3). According to the results obtained for the Green's coefficient $(C x)$, positive and above zero values were observed in $63.6 \%$ of the assessments (Table 3), indicating an aggregated distribution pattern. For the exponent $k$ of the negative binomial distribution, $27.2 \%$ of the values showed $k$ values $<2,45.4 \%$ of the values were between 2 and 8 , and $9.09 \%$ of the values were above 8 . These results indicate a highly aggregated pattern, moderate aggregation, and random distribution, respectively (Table 3). 


\section{Goodness of fit tests for frequency distribution}

The criterion for frequency distribution fit was determined using the sampling dates that showed non-significant chi-square test values. Where there were two significant results or two nonsignificant results, we adopted the lower chi-square value.

For the 2013/14 cropping season, the results for E. heros nymphs and adults on the SYN 1365 RR cultivar fit best to a negative binomial distribution for all the dates during which it was possible to perform the tests. This indicates that the distribution was aggregated (Table 4). Considering the 2014/15 season, in the nymph stage and the adult stage the best fit showed negative binomial distribution in $75.0 \%$ and $100.0 \%$ of assessments, respectively (Table 4).

Table 4. Chi-square tests $\left(X^{2}\right)$ for the fits of the Poisson and negative binomial distributions for Euschistus heros nymphs and adults in the SYN 1365 RR soybean crop in Jaboticabal, São Paulo, Brazil, during the 2013/14 and 2014/15 cropping seasons.

\begin{tabular}{|c|c|c|c|c|c|c|c|c|c|}
\hline \multirow[t]{3}{*}{ Sampling } & \multicolumn{5}{|c|}{ Nymphs } & \multirow{2}{*}{\multicolumn{4}{|c|}{$\begin{array}{c}\text { Adults } \\
\text { Negative Binomial }\end{array}$}} \\
\hline & \multicolumn{2}{|c|}{ Poisson } & \multicolumn{2}{|c|}{ Negative Binomial } & \multirow[b]{2}{*}{ d.f. } & & & & \\
\hline & & $X^{2}$ & d.f. & $X^{2}$ & & $X^{2}$ & d.f. & $X^{2}$ & d.f. \\
\hline \multirow{9}{*}{ 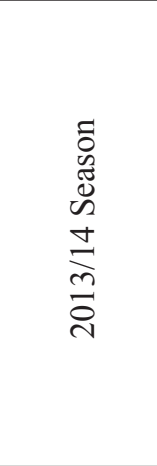 } & $50 \mathrm{DAE}$ & - & $\mathrm{I}$ & - & I & $1.6015^{\text {ns }}$ & 2 & $0.3529^{\text {ns }}$ & 1 \\
\hline & $57 \mathrm{DAE}$ & - & I & $-s^{2}<m$ & $-s^{2}<m$ & $78.9042 * *$ & 6 & $13.6780 *$ & 6 \\
\hline & $64 \mathrm{DAE}$ & $7.7464 *$ & 2 & $1.7106^{\mathrm{ns}}$ & 1 & $108.6463^{* *}$ & 8 & $5.3114^{\mathrm{ns}}$ & 6 \\
\hline & $71 \mathrm{DAE}$ & $34.5811 * *$ & 7 & $1.6162^{\mathrm{ns}}$ & 6 & $1.8627^{\mathrm{ns}}$ & 3 & $-s^{2}<m$ & $-s^{2}<m$ \\
\hline & $78 \mathrm{DAE}$ & $148.5037^{* *}$ & 11 & $3.6586^{\mathrm{ns}}$ & 5 & $44.4961 * *$ & 8 & $3.3441^{\mathrm{ns}}$ & 6 \\
\hline & $85 \mathrm{DAE}$ & $212.8970 * *$ & 13 & $5.1334^{\mathrm{ns}}$ & 5 & $70.9267 * *$ & 13 & $2.9790^{\mathrm{ns}}$ & 4 \\
\hline & $92 \mathrm{DAE}$ & $9.6350^{\mathrm{ns}}$ & 5 & $2.7778^{\mathrm{ns}}$ & 5 & $176.8592 * *$ & 14 & $3.7168^{\mathrm{ns}}$ & 5 \\
\hline & 99 DAE & $3.6575^{\mathrm{ns}}$ & 1 & $-s^{2}<m$ & $-s^{2}<m$ & $17.3888^{* *}$ & 8 & $3.8987^{\mathrm{ns}}$ & 6 \\
\hline & $106 \mathrm{DAE}$ & $14.0105^{* *}$ & 1 & $3.7405^{\mathrm{ns}}$ & 2 & $12.0437 * *$ & 3 & $3.9134^{\mathrm{ns}}$ & 4 \\
\hline \multirow{9}{*}{ 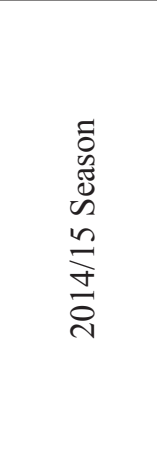 } & $51 \mathrm{DAE}$ & - & $\mathrm{I}$ & - & I & - & I & $-s^{2}<m$ & $-s^{2}<m$ \\
\hline & $58 \mathrm{DAE}$ & - & I & - & I & - & I & - & I \\
\hline & $65 \mathrm{DAE}$ & - & I & $-s^{2}<m$ & $-s^{2}<m$ & $3.4487^{\mathrm{ns}}$ & 1 & - & I \\
\hline & $72 \mathrm{DAE}$ & - & I & $-s^{2}<m$ & $-s^{2}<m$ & $0.8376^{\mathrm{ns}}$ & 1 & - & I \\
\hline & 79 DAE & $1.1398^{\mathrm{ns}}$ & 2 & $1.0262^{\mathrm{ns}}$ & 1 & $0.2341^{\mathrm{ns}}$ & 2 & $0.2206^{\mathrm{ns}}$ & 1 \\
\hline & $86 \mathrm{DAE}$ & $2.4784^{\mathrm{ns}}$ & 3 & $1.4317^{\mathrm{ns}}$ & 2 & $8.6055^{* *}$ & 3 & $5.2570^{\mathrm{ns}}$ & 2 \\
\hline & $93 \mathrm{DAE}$ & $3.3297^{\mathrm{ns}}$ & 1 & $4.8596^{*}$ & 1 & $8.9763 *$ & 3 & $1.3593^{\mathrm{ns}}$ & 2 \\
\hline & $100 \mathrm{DAE}$ & 7.4297* & 2 & $0.8526^{\mathrm{ns}}$ & 2 & $1.5653^{\mathrm{ns}}$ & 3 & $1.4444^{\mathrm{ns}}$ & 2 \\
\hline & $107 \mathrm{DAE}$ & $0.0935^{\mathrm{ns}}$ & 1 & $-s^{2}<m$ & $-s^{2}<m$ & $8.1315^{*}$ & 3 & $4.1746^{\mathrm{ns}}$ & 2 \\
\hline
\end{tabular}

$X^{2}=$ Statistic of the Chi-square test; d.f. = number of degrees of freedom of the Chi-square; I = insufficient; **Significant at $1 \%$

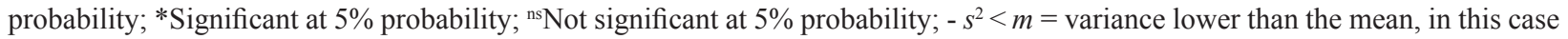
it is not sufficient to test the fit of the negative binomial distribution; DAE $=$ days after emergence of the plants.

For the first cropping season (2013/14), nymphs and adults on the M 7908 RR cultivar best fit a negative binomial distribution in $60.0 \%$ and $100.0 \%$ of the assessments, respectively, of which the tests were performed (Table 5). Thus, the distribution was aggregated for both nymphs and adults. With respect to the nymphs during the $2014 / 15$ season, the best fit showed a negative binomial distribution for all assessments (Table 5). Regarding the distribution of $E$. heros adults, there was a negative binomial fit in $83.3 \%$ of the assessments (Table 5). 
Table 5. Chi-square test $\left(X^{2}\right)$ of the fit of the Poisson and negative binomial distributions for Euschistus heros nymphs and adults in the M 7908 RR soybean crop in Jaboticabal, São Paulo, Brazil, during the 2013/14 and 2014/15 cropping seasons.

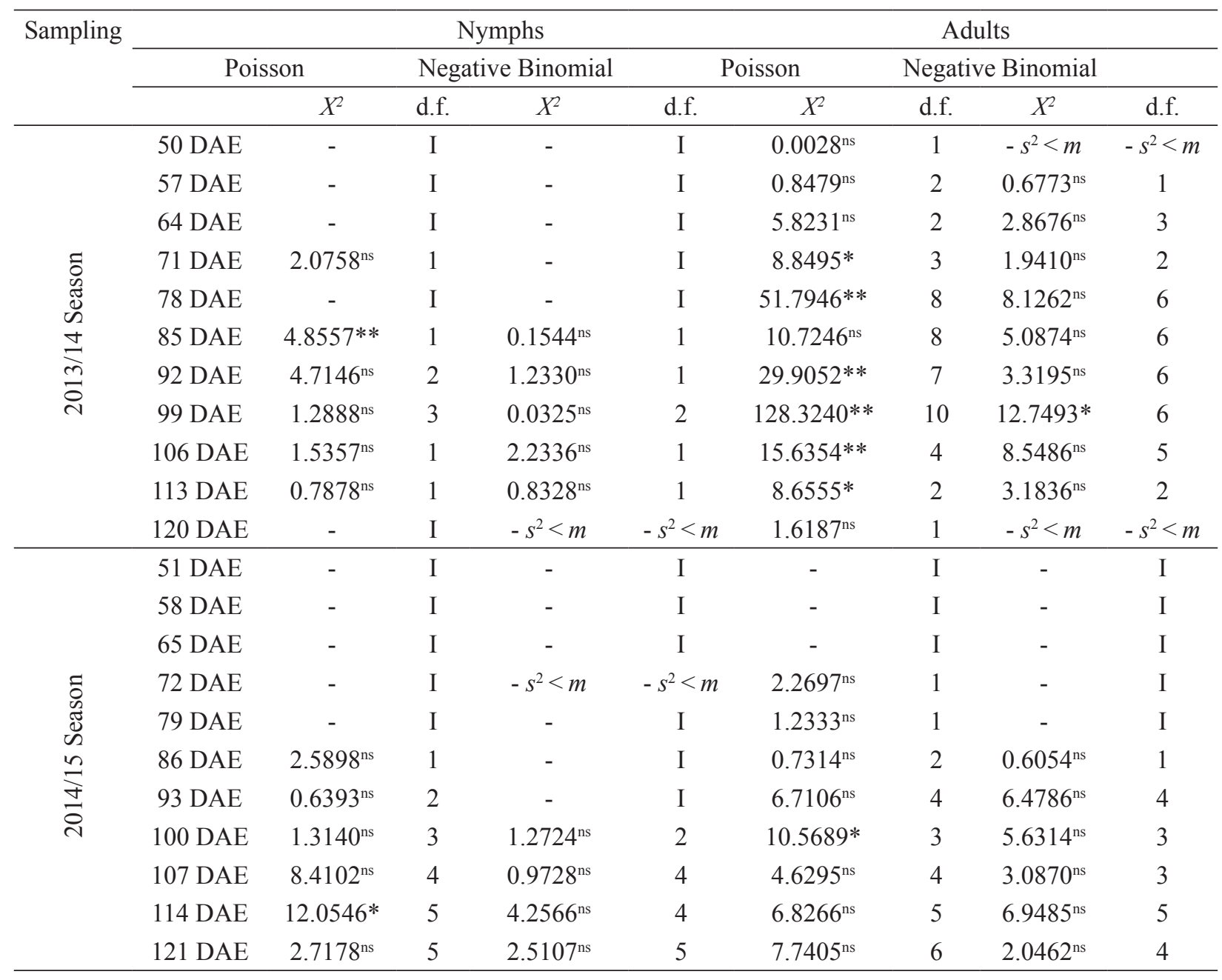

$X^{2}=$ Statistic of the Chi-square test; d.f. $=$ number of degrees of freedom of the Chi-square; $\mathrm{I}=$ insufficient; **Significant at $1 \%$ probability; *Significant at $5 \%$ probability; ${ }^{n}$ Not significant at $5 \%$ probability; $-s^{2}<m=$ variance lower than the mean, in this case it is not sufficient to test the fit of the negative binomial distribution; $\mathrm{DAE}=$ days after emergence of the plants.

With respect to the 2013/14 cropping season and the BRS Valiosa RR cultivar, the best fit of $E$. heros nymphs and adults showed negative binomial distribution in all the assessments in which it was possible to perform the fit tests for the distributions. The disposition of the brown stink bug was aggregated (Table 6). In the 2014/15 season, the best fit of the E. heros nymphs and adults showed negative binomial distribution in $80.0 \%$ and $100.0 \%$ of the evaluations, respectively (Table 6).

Based on the results obtained in the present work, it is noteworthy that the E. heros nymphs and adults had aggregated distributions in all cultivars assessed. 
Table 6. Chi-square test $\left(X^{2}\right)$ of the fit of Poisson and negative binomial distributions for Euschistus heros nymphs in the BRS Valiosa RR soybean crop in Jaboticabal, São Paulo, Brazil, during the 2013/14 and 2014/15 cropping seasons.

\begin{tabular}{|c|c|c|c|c|c|c|c|c|c|}
\hline \multirow[t]{3}{*}{ Sampling } & \multicolumn{6}{|c|}{ Nymphs } & \multirow{2}{*}{\multicolumn{2}{|c|}{$\begin{array}{c}\text { Adults } \\
\text { Negative Binomial }\end{array}$}} & \multirow[b]{3}{*}{ d.f. } \\
\hline & \multicolumn{2}{|c|}{ Poisson } & \multicolumn{2}{|c|}{ Negative Binomial } & \multicolumn{2}{|c|}{ Poisson } & & & \\
\hline & & $X^{2}$ & d.f. & $X^{2}$ & d.f. & $X^{2}$ & d.f. & $X^{2}$ & \\
\hline \multirow{12}{*}{ 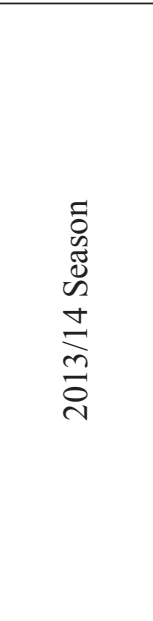 } & $50 \mathrm{DAE}$ & - & I & - & I & $4.8120^{*}$ & 1 & $0.1923^{\text {ns }}$ & 1 \\
\hline & $57 \mathrm{DAE}$ & - & I & - & I & $8.0446^{*}$ & 3 & $2.3764^{\mathrm{ns}}$ & 2 \\
\hline & $64 \mathrm{DAE}$ & - & I & - & I & $19.2310^{* *}$ & 4 & $5.4886^{\text {ns }}$ & 5 \\
\hline & $71 \mathrm{DAE}$ & $0.6349^{\mathrm{ns}}$ & 1 & - & I & 9.8794* & 3 & $7.6181^{*}$ & 2 \\
\hline & $78 \mathrm{DAE}$ & $8.3491^{\mathrm{ns}}$ & 1 & $0.8242^{\mathrm{ns}}$ & 1 & $18.1782 * *$ & 5 & $13.1263^{*}$ & 5 \\
\hline & $85 \mathrm{DAE}$ & $1.3707^{\mathrm{ns}}$ & 1 & $0.5292^{\mathrm{ns}}$ & 1 & $11.7931 *$ & 5 & $5.9102^{\mathrm{ns}}$ & 5 \\
\hline & $92 \mathrm{DAE}$ & $1.5103^{\mathrm{ns}}$ & 2 & $0.9461^{\mathrm{ns}}$ & 1 & $5.7391^{\mathrm{ns}}$ & 4 & $3.0340^{\mathrm{ns}}$ & 3 \\
\hline & 99 DAE & $13.5979 * *$ & 3 & $2.2289^{\mathrm{ns}}$ & 3 & $25.2351 * *$ & 6 & $7.7535^{\text {ns }}$ & 6 \\
\hline & $106 \mathrm{DAE}$ & $0.0329^{\mathrm{ns}}$ & 2 & $-s^{2}<m$ & $-s^{2}<m$ & $29.1061 * *$ & 3 & $8.5475^{\text {ns }}$ & 4 \\
\hline & $113 \mathrm{DAE}$ & $7.0104 *$ & 2 & $4.0324 *$ & 1 & $4.7764^{\mathrm{ns}}$ & 3 & $-s^{2}<m$ & $-s^{2}<m$ \\
\hline & $120 \mathrm{DAE}$ & $0.2763^{\mathrm{ns}}$ & 1 & - & I & $2.2143^{\mathrm{ns}}$ & 2 & $0.3117^{\mathrm{ns}}$ & 1 \\
\hline & 127 DAE & $3.2005^{\mathrm{ns}}$ & 1 & - & I & $2.3614^{\mathrm{ns}}$ & 1 & $0.1465^{\text {ns }}$ & 1 \\
\hline \multirow{12}{*}{ 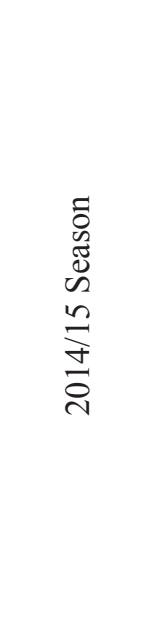 } & $51 \mathrm{DAE}$ & - & I & - & I & - & I & - & I \\
\hline & $58 \mathrm{DAE}$ & - & I & - & I & - & I & - & I \\
\hline & $65 \mathrm{DAE}$ & - & I & - & I & - & I & - & I \\
\hline & 72 DAE & - & I & - & I & - & I & $-s^{2}<m$ & $-s^{2}<m$ \\
\hline & 79 DAE & - & I & - & I & $0.3644^{\mathrm{ns}}$ & 1 & $0.2702^{\mathrm{ns}}$ & 1 \\
\hline & $86 \mathrm{DAE}$ & - & I & - & I & $2.0704^{\mathrm{ns}}$ & 2 & $1.2415^{\mathrm{ns}}$ & 2 \\
\hline & $93 \mathrm{DAE}$ & $0.4021^{\mathrm{ns}}$ & 2 & $0.2815^{\mathrm{ns}}$ & 1 & $5.6104^{\mathrm{ns}}$ & 6 & $3.3540^{\mathrm{ns}}$ & 5 \\
\hline & $100 \mathrm{DAE}$ & $2.4604^{\mathrm{ns}}$ & 2 & $3.4296^{\mathrm{ns}}$ & 2 & $1.3220^{\mathrm{ns}}$ & 2 & $1.1493^{\mathrm{ns}}$ & 1 \\
\hline & $107 \mathrm{DAE}$ & $7.6323^{\mathrm{ns}}$ & 5 & $7.1204^{\mathrm{ns}}$ & 4 & $9.5174^{\mathrm{ns}}$ & 5 & $1.7017^{\mathrm{ns}}$ & 4 \\
\hline & 114 DAE & $4.7356^{\mathrm{ns}}$ & 6 & $-s^{2}<m$ & $-s^{2}<m$ & $11.2475^{* *}$ & 5 & $-s^{2}<m$ & $-s^{2}<m$ \\
\hline & $121 \mathrm{DAE}$ & $10.5130^{\mathrm{ns}}$ & 8 & $4.2135^{\mathrm{ns}}$ & 6 & $32.3739 * *$ & 8 & $4.7746^{\mathrm{ns}}$ & 6 \\
\hline & $128 \mathrm{DAE}$ & $4.3676^{\mathrm{ns}}$ & 5 & $1.3740^{\mathrm{ns}}$ & 5 & $13.7201 *$ & 6 & $4.1193^{\mathrm{ns}}$ & 5 \\
\hline
\end{tabular}

$X^{2}=$ Statistic of the Chi-square test; d.f. = number of degrees of freedom of the Chi-square; I = insufficient; **Significant at $1 \%$

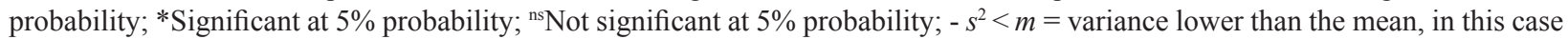
it is not sufficient to test the fit of the negative binomial distribution; DAE = days after emergence of the plants.

\section{Discussion}

\section{Spatial distribution of E. heros nymphs}

The results obtained in the present work corroborate those found by Fonseca et al. (2014) who studied the dispersion of $E$. heros in an intact $\mathrm{Bt}$ soybean cultivar that expressed the Cry1Ac protein as well as in a non-Bt soybean that was resistant to the herbicide glyphosate. In that case, the authors reported that the nymphs had an aggregated spatial pattern that best fits a negative binomial distribution.

Souza et al. (2013) observed that first to third instar nymphs of $E$. heros spread in an aggregated way in the M 7908 RR soybean cultivar (a transgenic cultivar resistant to glyphosate) as well as in its conventional isoline M-SOY 8001. In the same study, the authors concluded that the distribution of fourth and fifth instar nymphs varied from moderately aggregated to random. 
Thus, it is possible to verify that soybean cultivars resistant to the herbicide glyphosate and expressing the Cry1Ac protein do not alter the dispersion of $E$. heros. These results indicate that the behavior of $E$. heros is intrinsic; that is, it is aggregated regardless of the cultivars being studied.

According to Nascimento (1995), P. guildinii nymphs showed aggregated behavior in soybean cultivars at a normal development cycle; these results are similar to those found in the present study. In a study carried out by Santos (2014) with the same stink bug, it was concluded that nymphs distributed in small groups in early maturing soybean cultivars, meaning that they presented aggregated behavior. Thus, it was verified that the $P$. guildinii small green soybean stink bug has aggregated behavior, regardless of the stage of development of the soybean plants.

The results for nymphs observed in the present study are similar to those reported by Seiter et al. (2013) who studied the spatial distribution of Megacopta cribraria (Fabricius, 1798) (Hemiptera: Plataspidae) in the soybean crop. Nymphs from the pentatomids Euschistus servus (Say, 1832) and Nezara viridula (Linnaeus, 1758) (Heteroptera: Pentatomidae) in wheat crops also showed aggregated spatial distribution (REAY-JONES, 2014). Thus, it can be confirmed that, independently of the crop type, pentatomid nymphs distribute themselves in small groups; that is, they show aggregated behavior.

McPherson and McPherson (2000) pointed out that the spatial distribution pattern of pentatomid nymphs suggests that when food is available, dispersion is low, regardless of stage of development. This behavior is to conserve energy, so that the nymphs can move only when there is a need to search for food or shelter.

\section{Spatial distribution of E. heros adults}

The spatial distribution of E. heros adults was aggregated in the majority of the assessments carried out during the development of the crop. In the cultivars studied during the two agricultural seasons, there was no change in the behavior of this crop pest.

Souza et al. (2013) showed that the adult population of $E$. heros had a dispersion pattern that varied from moderately aggregated to random, whereas in the present study using cultivars of different stages of development, the distribution was aggregated.

This variation in the results is probably due to the higher incidence of the brown soybean stink bug during the years of the present study, since the occurrence of an individual in a plant increases the probability of occurrence in neighboring plants (PERECIN; BARBOSA, 1992).

Seiter et al. (2013), in a study carried out with M. cribraria on soybean crops in the Southeastern United States, and Reay-Jones (2014), assessing the spatial distribution of $E$. servus and $N$. viridula in wheat crops, concluded that adults of these insects distribute themselves in an aggregated manner in these crops. Their results corroborate those found in the present work for E. heros. Ricklefs (2003) reported that aggregation is probably the result of the social tendencies of individuals toward building a community with the goal of increasing their security and ensuring reproduction.

According to Fonseca et al. (2014), the distribution of brown soybean stink bugs in $\mathrm{Bt}$ and non-Bt soybeans varied among aggregated, random, and uniform patterns as the crop developed. The divergence of results obtained is possibly due to data analysis and different interpretations regarding the fit of the distributions studied. In contrast to the present study, when Fonseca et al. (2014), obtained variances equal to or greater than the mean, they tested the positive binomial (uniform) distribution model. However, according to Taylor (1984), the negative binomial (aggregate) distribution shows a greater variance than the mean. According 
to Southwood (1978), the Poisson (random) distribution is characterized by a variance equal to the mean.

According to Santos (2014), P. guildinii adults form small groups during the various phenological stages of the soybean crop. The results obtained in the present study as well as the results reported by Santos (2014), confirm that $P$. guildinii and $E$. heros have social behavior. Thus, regardless of the cultivars assessed in the various studies referred to here, the distribution of these pests is aggregated.

In the present study, the spatial distribution of E. heros nymphs and adults was aggregated. Thus, based on our results, it is possible to make sequential sampling plans. In this context, the development of a sequential sampling plan is fundamentally important within an Integrated Pest Management Program (IPM), because it is characterized by the use of samples of variable sizes, instead of using a fixed number of samples for a given area. This reduces the time and costs involved in the sampling (BARBOSA, 1992; SOUZA et al., 2014).

We conclude that spatial distribution is an intrinsic characteristic of the E. heros population; that is, the spatial distribution pattern was independent of the various stages of development of soybean cultivars.

\section{Conclusions}

The spatial distribution pattern of E. heros nymphs and adults is not altered by the varying stages of development of genetically modified soybean cultivars. Euschistus heros nymphs and adults had aggregated distribution that best fits the negative binomial distribution.

\section{Acknowledgments}

We are grateful to the Coordination for the Improvement of Higher Education Personnel (CAPES) for granting the doctoral scholarship to the first author, and to FCAV/UNESP for the infrastructure provided.

\section{References}

BARBOSA, J. C. A amostragem sequencial. In: FERNANDES, O. A.; CORREIA, A. C. B.; BORTOLI, S. A. de. (Ed.). Manejo integrado de pragas e nematoides. Jaboticabal: Funep, 1992. p. 205-211.

BOYER, W. P.; DUMAS, W. A. Soybean insect survey as used in Arkansas. Cooperative Economic Insect Report, Washington, v. 13, n. 6, p. 91-92, 1963.

BUENO, A. F.; ORCIAL, C. B.; FERNANDES, P. A.; FRANÇA NETO, J. B. Assessment of a more conservative stink bug economic threshold for managing stink bugs in Brazilian soybean production. Crop Protection, Guildford, v. 71, n. 5, p. 132-137, 2015.

BUENO, A. F.; PANIZZI, A. R.; CORRÊA-FERREIRA, B. S.; HOFFMANN-CAMPO, C. B.; SOSA-GÓMEZ, D. R.; GAZZONI, D. L.; HIROSE, E.; MOSCARDI, F.; CORSO, I. C.; OLIVEIRA, L. J.; ROGGIA, S. Histórico e evolução do manejo integrado de pragas da soja no Brasil. In: HOFFMANN-CAMPO, C. B.; CORRÊAFERREIRA, B. S.; MOSCARDI, F. (Ed.). Soja: manejo integrado de insetos e outros Artrópodes-Praga. Brasília: EMBRAPA, 2012. p. 37-74.

CENTRO DE PESQUISAS METEOROLÓGICAS E CLIMÁTICAS APLICADAS À AGRICULTURA CEPAGRI. Clima das cidades do Estado de São Paulo. Campinas, 2017. Disponível em: <http://www.cpa. unicamp.br/outras-informacoes/clima_muni_279.html>. Acesso em: 10 dez. 2017.

COSTA, M. G.; BARBOSA, J. C.; YAMAMOTO, P. T.; LEAL, R. M. Spatial distribution of Diaphorina citri Kuwayama (Hemiptera: Psyllidae) in citrus orchards. Scientia Agricola, Piracicaba, v. 67, n. 5, p. 546-554, 2010.

ELLIOTT, J. M. Some methods for the statistical analysis of samples of the benthic invertebrates. Ambleside: Freshwater Biological Association, 1979. 157 p.

FEHR, W. R.; CAVINESS, C. E. Stages of soybean development. Ames: Iowa State University of Science and Techonoly, 1977. 11 p. (Special Report, 80).

FONSECA, P. R.; FERNANDES, M. G.; JUSTINIANO, W.; CAVADA, L. H.; SILVA, J. A. N. Spatial distribution of adults and nymphs of Euschistus heros (F.) (Hemiptera: Pentatomidae) on Bt and Non-Bt Soybean. Journal of Agricultural Science, Ottawa, v. 6, n. 3, p. 131-142, 2014.

GREEN, R. H. Measurement of non-randomness in spatial distributions. Researches on Population Ecology, Tokyo, v. 8, n. 1, p. 1-7, 1966. 
MCPHERSON, J. E.; MCPHERSON, R. Stink bugs of economic importance in America North of Mexico. Boca Raton: FL, 2000. 253 p.

MIRANDA, M. A. C.; MASCARENHAS, H. A. A.; TANAKA, R. T.; BRAGA, N. R. Leguminosas: soja. In: FAHL, J. L.; CAMARGO, M. B. P.; PIZZINATTO, M. A.; BETTI, J. A.; MELO, A. M. T.; DEMARIA, I. C.; FURLANI, A. M. C. (Ed.). Boletim 200: instruções para as principais culturas econômicas. Campinas: Atual, 1998. p. 297-299.

MORISITA, M. Id-index, a measure of dispersion of individuals. Researches on Population Ecology, Tokyo, v. 4, n. 1, p. 1-7, 1962.

NASCIMENTO, J. E. Distribuição espacial e plano de amostragem sequencial para o percevejo pequeno, Piezodorus guildinii (Westwood, 1837) (HeteropteraPentatomidae) na cultura da soja. 1995. Dissertação (Mestrado em Entomologia Agrícola) - Faculdade de Ciências Agrárias e Veterinárias. Universidade Estadual Paulista, Jaboticabal.

PERECIN, D.; BARBOSA, J. C. Amostragem e análise estatística de dados de distribuição de contágio. Revista Matemática e Estatística, Jaboticabal, v. 10, n. 2, p. $207-$ 216, 1992.

RABINOVICH, J. E. Introducion a la ecologia de problaciones animales. Continental: México, 1980. 313 p.

REAY-JONES, F. P. F. Spatial distribution of stink bugs (Hemiptera: Pentatomidae) in wheat. Journal of Insect Science, Annapolis, v. 14, n. 98, p. 1-22, 2014.

RICKLEFS, R. E. A economia da natureza. Rio de Janeiro: Guanabara Koogan, 2003. 470 p.

RODRIGUES, T. R.; FERNANDES, M. G.; SANTOS, H. R. Distribuição espacial de Aphis gossypii (Glover) (Hemiptera, Aphididae) e Bemisia tabaci (Gennadius) biótipo B (Hemiptera, Aleyrodidae) em algodoeiro Bt e não-Bt. Revista Brasileira de Entomologia, Curitiba, v. 54, n. 1, p. 136-143, 2010.

SANTOS, L. S. Distribuição espacial e plano de amostragem sequencial para Piezodorus guildinii (Westwood, 1837) (Heteroptera: Pentatomidae) na cultura da soja transgênica $R R^{\circledR}$. 2014. Dissertação (Mestrado em Entomologia Agrícola) - Faculdade de Ciências Agrárias e Veterinárias. Universidade Estadual Paulista, Jaboticabal.

SEITER, N. J.; REAY-JONES, F. P. F.; GREEN, J. K. Within-field spatial distribution of Megacopta cribraria (Hemiptera: Plataspidae) in soybean (Fabales: Fabaceae). Environmental Entomology, Collegue Park, v. 42, n. 6, p. 1363-1374, 2013.

SOSA-GÓMEZ, D. R.; OMOTO, C. Resistência a inseticidas e outros agentes de controle em artrópodes associados à cultura da soja. In: HOFFMANN-CAMPO, C. B.; CORRÊA-FERREIRA, B. S.; MOSCARDI, F. (Ed.). Soja: manejo integrado de insetos e outros artrópodes-praga. Brasília: EMBRAPA, 2012. p. 673723.

SOSA-GÓMEZ, D. R.; SILVA, J. J. Neotropical brown stink bug (Euschistus heros) resistance to methamidophos in Paraná, Brazil. Pesquisa Agropecuária Brasileira, Brasília, v. 45, n. 7, p. 767-769, 2010.

SOUTHWOOD, T. E. R. Ecological methods. New York: Wiley, 1978. $525 \mathrm{p}$.

SOUZA, L. A.; BARBOSA, J. C.; GRIGOLli, J. F. J.; FRAGA, D. F.; MALDONADO JUNIOR, W.; BUSOLI, A. C. Spatial distribution of Euschistus heros (F.) (Hemiptera: Pentatomidae) in soybean. Neotropical Entomology, Londrina, v. 42, n. 4, p. 412-418, 2013.

SOUZA, L. A.; BARBOSA, J. C.; GRIGOLLI, J. F. J.; FRAGA, D. F.; MORAES, L. C.; BUSOLI, A. C. Sequential sampling of Euschistus heros (Heteroptera: Pentatomidae) in soybean. Scientia Agricola, Piracicaba, v. 71, n. 6, p. 464-471, 2014.

TAYLOR, L. R. Assessing and interpreting the spatial distributions of insect populations. Annual Review of Entomology, Palo Alto, v. 29, n. 1, p. 321-357, 1984.

WALD, A. Sequential analysis. New York: John Wiley \& Sons, $1947.211 \mathrm{p}$.

. Sequential tests of statistical hypothesis. Annals Mathematical Statistics, Ann Arbor, v. 16, n. 2, p. 117$186,1945$. 
